\title{
MANAJEMEN KURIKULUM MADRASAH ALIYAH PROGRAM KEAGAMAAN MAN 1 SURAKARTA
}

\author{
Norma Chunnah Zulfa, Pardjono \\ Program Studi Manajemen Pendidikan PPs UNY, Universitas Negeri Yogyakarta \\ zulpha_04@yahoo.com,jpardjono@yahoo.com
}

\begin{abstract}
Abstrak
Penelitian ini bertujuan untuk mengungkap manajemen kurikulum MAPK MAN 1 Surakarta mencakup perencanaan, pelaksanaan, dan evaluasi kurikulum serta kendala manajemen kurikulum. Penelitian ini menggunakan metode kualitatif pendekatan studi kasus. Subjek penelitian terdiri dari kepala madrasah, wakil kepala madrasah program keagamaan, pembina asrama, dan guru. Objek penelitian: kegiatan pembelajaran, kegiatan asrama, dan kondisi sekolah. Pengumpulan data menggunakan metode wawancara, pengamatan, dan analisis dokumen. Instrumen penelitian adalah peneliti dan pedoman wawancara, observasi dan analisis dokumen. Keabsahan data dilakukan dengan uji credibilty, transferability, dependability, dan confirmability. Analisis data menggunakan analisis interaktif Miles-Huberman terdiri dari reduksi data, penyajian data, dan penarikan kesimpulan. Hasil penelitian menunjukkan bahwa perencanaan kurikulum dilakukan melalui workshop berpedoman pada kurikulum nasional, pengembangan keunggulan lokal, dan adaptasi sistem pondok pesantren. Evaluasi kurikulum dilakukan dalam bentuk ujian semester, ujian madrasah dan ujian nasional menggunakan bahasa arab. Faktor-faktor kendala manajemen kurikulum MAPK antara lain: modul program keagamaan belum baku dan buku diktat kurang sistematis; kurangnya ketelatenan guru membuat perangkat pembelajaran dan penguasaan teknologi komputer; sarana prasarana yang belum memadai; masalah kedisiplinan siswa MAPK dalam mengikuti pembelajaran; padatnya kegiatan sekolah, asrama, dan organisasi mengurangi fokus belajar siswa; dan kemampuan bahasa anak yang belum mampu memahami teks secara keseluruhan.
\end{abstract}

Kata kunci: manajemen kurikulum, program keagamaan

\section{THE CURRICULUM MANAGEMENT OF THE ISLAMIC RELIGIOUS PROGRAM OF MADRASAH ALIYAH NEGERI 1 SURAKARTA}

\begin{abstract}
This research aimed to reveal the curriculum management of islamic religious program of MAN 1 Surakarta consisting of curriculum planning, implementation, evaluation, and the obstacle of curriculum management. This research used the qualitative method case study approach. The subjects were the principal, vice principal for the islamic religious program, dormitory advisors, and teachers. The objects were teaching process, dormitory's activities, and the condition of the school. The data were collected through interviews, observations, and documents analysis. The research instrument was the researcher herself and interview, observation, and document analysis guide. The validity of the data was reached through credibility, transferability, dependability, and confirmability test. The data were analyzed using Miles-Huberman's interactive model of analysis consisting of data reduction, data display, and conclusion drawing. The results show that the curriculum planning held through workshop based on the national curriculum, local excellent development and islamic boarding school system adaptation. The curriculum evaluation held through half year exams, school exams, and national exams using arabic language. The obstacle of curriculum management at MAPK includes the non standardized module, the unsystematic hand out, the lack of teacher conscience in making teaching sets and inability to use computer technology, the minimum facilities, the crowded activities reduces students' focus on study, students' inability to understand the texts completely.
\end{abstract}

Keywords: the curriculum management, Islamic religious program 


\section{Pendahuluan}

Demi terlaksananya layanan pendidikan yang bermutu bagi siswa dalam konteks MBS maka diperlukan manajemen dalam bidang pendidikan, yaitu sebuah proses manajemen dalam pelaksanaan tugas pendidikan dengan mendayagunakan segala sumber daya secara efisien untuk mencapai tujuan efektif. Manajemen pendidikan ditujukan untuk mengelola garapan yang dikembangkan dalam sistem pendidikan meliputi peserta didik, tenaga kependidikan, kurikulum, sarana prasarana, keuangan, kemitraan dengan masyarakat, serta bimbingan dan pelayananan khusus (Engkoswara \& Komariah, 2010: 88).

Sama halnya dengan manajemen pendidikan Islam sebagai proses pengelolaan lembaga pendidikan Islam secara islami dengan cara menyiasati sumbersumber belajar dan hal-hal lain terkait untuk mencapai tujuan pendidikan Islam secara efektif dan efisien demi meningkatkan mutu lembaga pendidikan Islam. Selama ini, madrasah dianggap sebagai lembaga pendidikan Islam yang mutunya lebih rendah daripada mutu lembaga pendidikan lainnya, terutama sekolah umum. Walaupun beberapa madrasah justru lebih maju daripada sekolah umum, namun belum mampu menghapus kesan negatif yang ada (Qomar, 2002: 80). Manajemen pendidikan Islam merupakan solusi untuk meningkatkan mutu pendidikan Islam yang memuat komponen-komponen dasar manajemen pendidikan Islam yang mutlak harus ada dalam proses pendidikan Islam yaitu manajemen personalia, kesiswaan, kurikulum, dan sarana prasarana pendidikan Islam (Qomar, 2002: 128).

Kurikulum sebagai salah satu komponen penting dalam pendidikan perlu dikelola agar dapat memberikan kontribusi terhadap peningkatan mutu pendidikan. Diungkapkan oleh Rifai \& Murni (2010: 86) bahwa di antara kegiatan pokok upaya peningkatan kualitas dan relevansi pendidikan menengah adalah menyusun kurikulum yang berbasis kompetensi dasar sesuai de- ngan kebutuhan dan potensi daerah, mampu meningkatkan kreativitas guru guru, inklusif dan tidak bias gender sesuai dengan kapasitas peserta didik, serta menekankan perlunya peningkatan keimanan dan ketakwaaan, wawasan kebangsaaan, kesehatan jasmani, kepribadian yang berakhlak mulia, beretos kerja, memahami hak dan kewajiban, serta meningkatkan penguasaan ilmu-ilmu dasar. Hal ini mengimplikasikan bahwa dalam penyelenggaraan pendidikan dibutuhkan manajemen kurikulum agar relevansi pendidikan dengan kebutuhan masyarakat dapat terpenuhi.

Kurikulum pendidikan islam yang menonjolkan tujuan agama dan akhlak pada berbagai tujuan, kandungan, metode, alat, dan tekniknya harus menyesuaikan dengan tuntutan zaman tanpa harus keluar dari nilai-nilai keislaman yang menjadi ciri khasnya. Oleh karena itu, kurikulum pendidikan islam perlu dikelola dengan baik agar menghasilkan lulusan yang mampu bersaing dengan lulusan sekolah umum dengan memiliki keunggulan di bidang penguasaan ilmu agama islam. Melalui manajemen kurikulum untuk pendidikan Islam diharapkan mampu mewujudkan pengelolaan kurikulum yang mendukung pencapaian tujuan pendidikan Islam itu sendiri (Qomar, 2002: 151).

Kurikulum madrasah dengan ciri khas nilai-nilai keislaman dalam penyelenggaraan pendidikannya tetap mengacu pada Permendiknas Nomor 22 Tahun 2006 tentang standar isi dan diatur secara lebih rinci melalui Permenag Nomor 2 Tahun 2008 tentang standar kompetensi dan standar isi pendidikan agama Islam dan bahasa arab di madrasah, serta memperhatikan surat edaran dirjen pendidikan islam nomor DJ.II.1/PP.00/ED/681/2006 tanggal 1 agustus 2006 tentang pelaksanaan standar isi yang intinya bahwa madrasah dapat meningkatkan kompetensi lulusan dan mengembangkan kurikulum dengan standar lebih tinggi. Struktur kurikulum madrasah untuk mata pelajaran pendidikan agama Islam dirinci menjadi empat mata pelajaran yaitu al-qur'an hadits, akidah akhlak, fikih, dan sejarah 
kebudayaan Islam sehingga beban belajar siswa pada madrasah menjadi bertambah setiap minggunya. Struktur kurikulum mata pelajaran agama islam pada madrasah ini berlaku untuk kelas X dan kelas XI, XII pada setiap jurusan baik IPA, IPS maupun bahasa. Bagi madrasah yang menyelenggarakan program keagamaan maka struktur kurikulumnya berbeda dari struktur kurikulum yang telah dijelaskan sebelumnya. Struktur kurikulum program keagamaan untuk mata pelajaran pendidikan agama islam dirinci menjadi tujuh mata pelajaran yaitu akhlak, sejarah kebudayaan islam, bahasa arab,tafsir, hadits, fikih dan ilmu kalam. Ilmu-ilmu keislaman dipelajari secara mendalam dan menyeluruh pada program keagamaan sehingga desain kurikulum yang dimiliki pun berbeda.

Madrasah Aliyah Negeri 1 Surakarta yang menyelenggarakan program keagamaan sebagai salah satu program unggulannya pun mendesain kurikulum untuk program keagamaaan menjadi $70 \%$ ilmu agama dan 30\% ilmu umum. Kekhasan kurikulum ini tampak pada struktur kurikulum yang mengajarkan ilmu-ilmu agama dengan porsi yang lebih banyak daripada ilmu umum, pelajaran agama islam terdiri dari mata pelajaran aqidah akhlak, qur'an hadits, ilmu tafsir, ilmu hadits, fiqih, ushul fiqih, tasawwuf, sejarah peradaban islam, bahasa arab dan sisanya adalah ilmu umum meliputi kewarganegaraan, bahasa dan sastra indonesia, matematika, pendidikan jasmani, TIK, kesenian, dan bahasa inggris. Buku-buku sumber yang digunakan untuk pelajaran agama islam pada program keagamaan menggunakan bahasa arab sehingga tingkat kesulitan siswa berbeda dari siswa MAN biasa. Sistem pendidikan yang digunakan pada program keagamaan menganut sistem pondok pesantren yang mengharuskan siswa tinggal di asrama selama menempuh pendidikan. Program keagamaan ini didesain untuk menyiapkan peserta didik yang memiliki integritas keislaman dan kemampuan ilmu-ilmu keislaman yang memadai guna melanjutkan ke perguruan tinggi islam baik di dalam maupun di luar negeri.

Madrasah aliyah program khusus menggunakan KTSP meski dalam pelaksanaan tidak sepenuhnya KTSP, dan kurikulum lokal adaptasi dari lembaga ilmu pengetahuan islam dan arab (LIPIA) artinya ada beberapa mata pelajaran yang diajarkan di MAPK menggunakan buku ajar dari LIPIA dan adaptasi kurikulum pesantren salaf terutama untuk kajian kitab-kitab kuning. Demi mendukung pelaksanaan kurikulum yang diterapkan, maka MAPK melaksanakan pembelajaran yang terbagi dalam tiga kelompok, yaitu pembelajaran formal di pagi hari, pembelajaran tutorial di sore hari, dan kajian kitab kuning serta praktik kebahasaaan di asrama. Pembelajaran pagi dilaksanakan untuk memenuhi standar kompetensi lulusan siswa MAPK s yang tertera dalam Permendiknas Nomor 23 Tahun 2006 tentang standar kompetensi lulusan pendidikan dasar dan menengah dan Permenag Nomor 2 Tahun 2008 tentang standar kompetensi lulusan dan standar isi pendidikan agama islam dan bahasa arab di madrasah. Tutorial dilakukan untuk mengoptimalkan penguasaan berbahasa siswa MAPK yaitu bahasa arab dan inggris, pembelajaran di asrama memfokuskan pada praktik kebahasaaan dalam kegiatan sehari-hari dan memperdalam kajian-kajian kitab kuning.

Penyelenggaraan kurikulum MAP$\mathrm{K}$ memunculkan hal-hal menarik diantaranya: ada beberapa kegiatan pembelajaran yang tidak tercantum dalam dokumen KTSP namun tetap dilaksanakan karena merupakan tradisi, MAPK memiliki banyak hidden curriculum yang melandasi pelaksanaan pembelajaran di MAPK. Madrasah aliyah program keagamaan menyusun kurikulum KTSP meski pelaksanaannya belum melibatkan semua pihak, penyusunan kurikulum MAPK disesuaikan dengan filosofi MAPK, dan tidak mau terjebak dengan berbagai kebijakan pemerintah yang tidak sesuai dengan filosofi MAPK. Saat ini, MAPK mengalami kekurangan guru sehingga ada guru yang 
mengalami kelebihan jam mengajar. Perhatian pemerintah terhadap peningkatan kompetensi guru MAPK pun minim, jarang diadakan pelatihan bagi guru bahkan dapat dikatakan tidak pernah ada, hanya sebatas workshop dari pihak internal sekolah. Pihak yang tidak kalah penting dalam pelaksanaan kurikulum MAPK adalah pembina asrama. Tugas dan peran pembina asrama adalah memotivasi, mengarahkan, membimbing, dan memberi contoh kepada siswa/siswi MAPK baik di asrama maupun di sekolah. Meski pada praktiknya, rasio jumlah pembina asrama dengan jumlah siswa MAPK yang tidak seimbang sehingga perannya kurang optimal.

Kemudian alokasi waktu mata pelajaran yang dirasa mampu dipelajari oleh siswa secara mandiri dipersingkat tatap mukanya, namun kompetensi dasar tetap tercapai, misalnya mata pelajaran pendidikan kewarganegaraan yang harusnya 2 (dua) jam pelajaran per minggu dipersingkat menjadi 1 (satu) jam pelajaran per minggu, pelajaran bahasa Indonesia yang seharusnya 4 (empat) jam pelajaran per minggu dipersingkat menjadi 3 (tiga) jam per minggu. Alokasi mata pelajaran bahasa arab mencapai tujuh jam pelajaran per minggu, berbeda dari panduan yang ada dalam standar isi tentang struktur kurikulum untuk program keagamaan. Hal ini terjadi karena mata pelajaran bahasa arab menjadi prioritas dalam pembelajaran MAPK.

Melalui penelitian ini akan dikaji lebih mendalam tentang manajemen kurikulum madrasah aliyah program keagamaan MAN 1 Surakarta, bagaimana MAPK melaksanakan kurikulum dari tahap perencanaan kurikulum, pelaksanaan kurikulum, dan evaluasi kurikulum. Permasalahan di MAPK MAN 1 Surakarta sebagai berikut: (1) tidak semua kegiatan pembelajaran MAPK tertulis di dokumen KTSP, (2) belum semua guru terlibat dalam penyusunan KTSP, (3) perhatian pemerintah terhadap peningkatan kompetensi guru MAPK masih kurang, (4) MAPK kekurangan jumlah guru sehingga menimbulkan kelebihan jam mengajar bagi beberapa guru, (5) MAPK mengurangi jam pelajaran untuk mata pelajaran tertentu yang dirasa mampu dipelajari sendiri oleh siswa, (6) rasio jumlah pembina asrama dan siswa tidak seimbang, (7) jumlah jam belajar siswa MAPK yang sangat padat.

Penelitian difokuskan pada manajemen kurikulum madrasah aliyah program keagamaan MAN 1 Surakarta, meliputi perencanaan, pelaksanaan, dan evaluasi kurikulum, serta kendala manajemen kurikulum MAPK MAN 1 Surakarta. Tujuan penelitian yang ingin dicapai melalui penelitian ini adalah untuk mendeskripsikan lebih dalam tentang (1) perencanaan kurikulum MAPK MAN 1 Surakarta, (2) pelaksanaan kurikulum MAPK MAN 1 Surakarta, (3) 3valuasi kurikulum MAPK MAN 1 Surakarta, (4) faktor-faktor yang menjadi kendala manajemen kurikulum MAPK MAN 1 Surakarta

Manfaat penelitian ini diharapkan dapat menjadi acuan bagi pengembangan teori manajemen kurikulum pada lembaga pendidikan berciri khas ilmu-ilmu keislaman. Kemudian hasil penelitian diharapkan memberikan manfaat bagi madrasah dapat mengevaluasi manajemen kurikulum yang terlaksana sebagai bahan pertimbangan bagi kepala madrasah, guru dan pembina asrama dalam mengelola kurikulum MAP$\mathrm{K}$ selanjutnya, sekolah lain dapat mengambil hal-hal positif dari hasil penelitian manajemen kurikulum MAPK dan menjadikannya sebagai contoh dalam mengelola kurikulum di sekolah masing-masing.

Definisi kurikulum diantaranya: "the curriculum is all of the educative experiences learners have in an educational program, the purpose of which is to achieve broad goals and related specific objectives that have been developed within a framework of theory and research, past and present professional practice, and the changing needs of society" (Parkay, Hass \& Anctil (2010: 3).

Sukmadinata (2012: 102-112) menyebutkan bahwa komponen kurikulum antara lain: tujuan, bahan ajar, strategi mengajar, media mengajar, evaluasi pengajaran, penyempurnaan pengajaran. Kurikulum memiliki tiga peran (Sanjaya, 2010: 
10-11) yaitu: (1) peranan konservatif melestarikan berbagai nilai budaya sebagai warisan masa lalu, (2) peran kreatif bermakna bahwa kurikulum harus mampu menjawab setiap tantangan sesuai dengan perkembagan dan kebutuhan masyarakat yang cepat berubah, (3) peran kritis dan evaluatif yaitu menyeleksi nilai dan budaya mana yang perlu dipertahankan, dan nilai atau budaya baru mana yang harus dimiliki anak didik.

Menurut pendapat Rusman (2009: 3) manajemen kurikulum adalah sebagai suatu sistem pengelolaan kurikulum yang kooperatif, komprehensif, sistemik, dan sistemik dalam rangka mewujudkan ketercapaian tujuan kurikulum. Lunenberg \& Orstein (2000: 441-445) menyebutkan bahwa pengembangan kurikulum terdiri dari tiga proses yaitu perencanaan, pelaksanaan, dan evaluasi kurikulum. Kemudian dijelaskan secara lebih rinci melalui model manajerial dari Saylor bahwa proses mengelola kurikulum diawali dengan mengidentifikasi kekuatan-kekuatan eksternal dan dasar-dasar kurikulum yang mempengaruhi tujuan dan sasaran kurikulum untuk diwujudkan dalam desain kurikulum, implementasi, dan evaluasi kurikulum.

\section{Metode Penelitian}

Jenis Penelitian

Penelitian ini menggunakan pendekatan penelitian kualitatif dengan pendekatan studi kasus karena penelitian ini mengkaji tentang manajemen kurikulum madrasah aliyah program keagamaan di MAN 1 Surakarta dilihat dari perencanaan, pelaksanaan, evaluasi kurikulum, dan faktor yang menjadi kendala manajemen kurikulum MAPK secara mendalam.

Tahapan-tahapan manajemen kurikulum adalah: (1) tahap perencanaan, diungkapkan oleh Glatthorn, Boschee \& Whitehead (2009: 134) "curriculum planning is the specification and sequencing of major decisions to be mad)e in the future with regard to the curriculum", (2) tahap pelaksanaan,
Lunenberg \& Orstein (2000: 444) mengemukakan bahwa implementasi/pelaksanaan kurikulum utamanya terfokus pada aktivitas instruksional yang memfasilitasi atau melaksanakan desain kurikulum. Implementasi kurikulum meliputi supervisi terhadap instruksi, perencanaan guru, supervisor dan rapat sebagaimana program pengembangan staf, (3) tahap evaluasi adalah menilai suatu kurikulum sebagai program pendidikan untuk mengetahui efisiensi, efektivas, relevansi, dan produktivitas progam dalam mencapai tujuan pendidikan. Evaluasi kurikulum dimaksudkan sebagai feedback terhadap tujuan, materi, metode dan sarana, dalam rangka mengembangkan kurikulum lebih lanjut. Evaluasi kurikulum bertujuan untuk memperbaiki dan menyempurnakan program pendidikan dan strategi bagaimana program itu dilaksanakan (Mudlofir, 2012: 1112).

Penelitian tentang manajemen kurikulum pernah dilakukan oeh Bueraheng (2010) tentang manajemen kurikulum program pendidikan agama Islam kelas tsanawiyah di madrasah Azizstan Thailand menghasilkan kesimpulan sebagai berikut: (a) kurikulum disusun melalui workshop para guru dan pimpinan untuk mengintegrasikan muatan-muatan lokal dan kurikulum Al-Azhar Mesir, (b) kurikulum dilaksanakan melalui proses pembelajaran menerapkan metode yang bervariasi yaitu mengkombinasikan metode ceramah, tanya jawab, tugas, diskusi, demonstrasi, latihan, dan problem solving, (c) evaluasi untuk menentukan kelulusan siwa dilihat dari hasil ujian di kelas, I-net pemerintah Thai juga dari hasil praktek mengajar tadika di lapangan. Untuk ujian dari mesir ditempuh oleh siswa yang ingin mendapat beasiswa studi di al azhar kairo mesir, (d) faktor-faktor penghambat adalah: masih terdapat guru yang mengajar tidak sesuai dengan kompetensinya dan kurang meman-faatkan sarana dan media yang tersedia, padatnya waktu belajar siswa sehingga tidak ada waktu untuk mempelajari ulang materi yang diajarkan, dan sarana prasarana dan biaya terbatas. 
Kemudian, Nugroho (2008) tentang manajemen kurikulum kelas internasional di SMA negeri 1 kota Yogyakarta. Kesimpulan yang dihasilkan antara lain: (a) perencanaan kurikulum kelas internasional di SMA negeri 1 kota Yogyakarta diawali dengan workshop, dengan menganalisis muatan-muatan yang ada dalam kurikulum nasional dan dari kurikulum internasional (University of Cambridge), (b) pelaksanaan kurikulum kelas internasional di SMA negeri 1 kota Yogyakarta menggunakan kurikulum nasional yang diintegrasikan dengan kurikulum dari University of Cambridge London dengan pembelajaran yang menumbuhkan semangat long life education serta mengembangkan multi kecerdasan melalui metode yang menyenangkan dan bervariasi yaitu metode pemanfaatan alam/lingkungan, sumber belajar di sekolah, dan media elektronik, (c) evaluasi kurikulum yang diterapkan di kelas internasional adalah evaluasi kurikulum nasional walau untuk evaluasi dari Cambridge University dapat ditempuh oleh para siswa namun tidak menentukan kelulusan seorang siswa dari kelas internasional, (d) faktor-faktor yang menghambat pelaksanaan manajemen kurikulum adalah kurangnya dukungan stakeholder, kurangnya bimbingan teknis, SDM yang belum memadai

Berdasarkan kajian-kajian penelitian yang relevan di atas, maka dapat diketahui persamaan dan perbedaan antara kedua penelitian yang telah dilakukan dengan penelitan tentang manajemen kurikulum MAPK MAN 1 Surakarta. Hal ini memudahkan peneliti dalam menentukan posisi penelitian yang dilakukan terhadap penelitian-penelitian sebelumnya. Persamaan antara kedua penelitian di atas dengan penelitian yang dilakukan adalah persamaan objek penelitian yaitu tentang kurikulum. Penelitian Bueraheng dan Nugroho tentang manajemen kurikulum. Perbedaan penelitian manajemen kurikulum MAPK MAN 1 Surakarta dengan kedua penelitian sebelumnya adalah kurikulum MAPK merupakan kurikulum sebuah program unggulan pada jenjang pendidik- an madrasah dengan mengadopsi sistem pendidikan pondok pesantren dan adaptasi kurikulum LIPIA dalam penyelenggaraan pendidikannya berbeda dengan penelitian Bueraheng yang mendeskripsikan tentang manajemen kurikulum di madrasah Thailand dengan adopsi kurikulum Al-Azhar Mesir. Kemudian penelitian Nugroho difokuskan pada kelas internasional SMA, sedangkan penelitian manajemen kurikulum MAPK dilakukan di madrasah.

Merujuk pada persamaan dan perbedaan dari kedua penelitian sebelumnya, maka penelitian tentang manajemen kurikulum MAPK perlu dilakukan karena belum pernah dilakukan sebelumnya sehingga masih memungkinkan untuk menemukan fakta-fakta baru melalui penelitian. Diharapkan hasil temuan dari manajemen kurikulum MAPK MAN 1 Surakarta semakin memperkaya kajiankajian tentang manajemen kurikulum pada lembaga pendidikan Islam.

\section{Waktu dan Tempat Penelitian}

Penelitian dilakukan di madrasah aliyah program keagamaan (MAPK) MAN 1 Surakarta yang beralamat di Jl Sumpah Pemuda No 25 Kadipiro Surakarta pada bulan Februari hingga April 2013.

\section{Subjek Penelitian}

Subjek penelitian ini adalah kepala madrasah, wakil kepala madrasah program keagamaan, guru MAPK, dan pembina asrama. Kepala madrasah sebagai pimpinan lembaga diasumsikan mengetahui banyak informasi tentang manajemen kurikulum MAPK. Wakamad program keagamaan ikut serta dalam menentukan rancangan kurikulum MAPK, pelaksanaan dan evaluasi kurikulum. Pembina asrama adalah penanggungjawab seluruh kegiatan siswa siswi MAPK di asrama sehingga memiliki informasi yang lengkap tentang pelaksanaan pembelajaran di asrama. Guru dipilih karena terlibat langsung dengan siswa dalam pelaksanaan kurikulum di kelas sehingga mengetahui tingkat keter- 
capaian serta hambatan-hambatan yang dihadapi selama melaksanakan kurikulum.

Prosedur

Penelitian diawali dengan studi pendahuluan untuk mengetahui kondisi awal MAPK MAN 1 Surakarta sehingga ditemukan masalah-masalah yang perlu dicarikan solusinya. Permasalahan yang ditemukan di lokasi penelitian kemudian dituliskan dalam bentuk proposal penelitian yang menjadi pedoman dalam pengumpulan data selanjutnya, baik tentang metode, instrumen, maupun jenis data yang harus dikumpulkan. Langkah selanjutnya adalah melakukan penelitian untuk memperoleh data sesuai fokus penelitian yang telah ditetapkan, yaitu manajemen kurikulum MAPK MAN 1 Surakarta mencakup perencanaa, pelaksanaan, dan evaluasi kurikulum serta kendala-kendala manajemen kurikulum. Datadata yang telah dikumpulkan kemudian dianalisis untuk menjawab pertanyaan penelitian dengan mendeskripsikan kondisi yang sebenarnya di lokasi penelitian, disimpulkan dan mengajukan saran-saran untuk permasalahan yang ditemukan.

Data, Intrumen, dan Teknik Pengumpulan Data

Data yang dikumpulkan dalam penelitian ini adalah data tentang manajemen kurikulum MAPK MAN 1 Surakarta baik berupa pernyataan, informasi, dokumen, maupun hasil pengamatan terhadap kegiatan yang sesuai dengan tujuan penelitian. Data dikumpulkan menggunakan metode wawancara, pengamatan, dan analisis dokumen. Instrumen penelitian adalah peneliti dan pedoman wawancara, pengamatan, dan analisis dokumen.

Wawancara digunakan untuk menggali data tentang manajemen kurikulum MAPK mulai dari tahap perencanaan, pelaksanaan hingga evaluasi kurikulum MAPK dari para informan yaitu kepala madrasah, wakamad MAPK, guru MAPK, dan pembina asrama. Wawancara dilaksanakan secara terstruktur mengguna- kan pedoman wawancara meski pada pelaksanaan wawancara, pertanyaan yang diajukan kepada informan terkadang tidak langsung mengenai pokok penelitian, namun peneliti tetap mengacu pada pedoman wawancara agar data yang terkumpul sesuai dengan kebutuhan penelitian.

Observasi dilakukan untuk mengamati kondisi fisik dan nonfisik, kondisi fisik yang diamati antara lain: sekolah, asrama, perpustakaan sekolah, perpustakaan asrama, ruang kelas, dan sarana prasarana lainnya. Kondisi nonfisik yang diamati diantaranya kegiatan-kegiatan yang terkait dengan manajemen kurikulum MAPK di MAN 1 Surakarta, yaitu pembelajaran di kelas, dan kegiatan asrama. Peneliti mengamati proses pembelajaran yang berlangsung tanpa terlibat di dalamnya dan mencatat hal-hal penting terkait pengumpulan data penelitian Kegiatankegiatan asrama yang diamati oleh peneliti diantaranya kegiatan tahfidzul qur'an, conversation atau muhadatsah, pengajian kitab dan bimbingan belajar yang diberikan pembina asrama kepada siswi di asrama.

Analisis dokumen ditujukan untuk mencermati dan menganalisis dokumen terkait manajemen kurikulum MAPK, yaitu: dokumen kurikulum MAPK, data guru, data siswa, kalender akademik, jadwal pelajaran, program kerja organisasi pelajar program keagamaan tentang kegiatan asrama. Analisis dokumen digunakan untuk mengungkap informasi yang tidak dapat dilakukan dengan wawancara atau observasi yaitu berupa data-data tertulis yang belum diungkapkan secara lengkap oleh informan.

\section{Teknik Analisis Data}

Teknis analisis data penelitian kualitatif bersifat induktif, yaitu analisis berdasarkan data yang diperoleh untuk menemukan konsep dari fokus penelitian yang diteliti. Analisis data pada penelitian ini terdiri dari tiga tahapan yaitu reduksi data, penyajian data, dan penarikan kesimpulan/verifikasi. 
Langkah yang dilakukan untuk memudahkan analisis adalah mengelompokkan data sesuai kategori masig-masing yaitu hasil wawancara, hasil observasi kelas, catatan lapangan dan analisis dokumen. Setiap data diberi kode yang diambil dari huruf awal metode pengumpulan data, nama responden, dan waktu pengambilan data. Contohnya, data hasil wawancara akan diberikan kode W/KM/ 142-'13 artinya W adalah wawancara, KM adalah inisial untuk kepala madrasah, dan 14-2-'13 untuk waktu pengambilan data yaitu 14 Februari 2013. Hasil observasi diberikan kode $\mathrm{HO}$ dengan format penulisan $\mathrm{HO} / \mathrm{AY} / 13-2$ '13 yang bermakna HO untuk hasil observasi, AY untuk inisial nama guru yang mengajar, 13-2'13 adalah waktu observasi yaitu 13 Februari 2013. Catatan lapangan diberikan kode CL disertai urutan I, II dan seterusnya untuk menandakan kunjungan peneliti dengan format penulisan CL/I/6-3-'13 artinya catatan lapangan pada kunjungan pertama pada tanggal 6 Maret 2013. Nantinya, hasil wawancara, hasil observasi, catatan lapangan disertai keterangan poin dan halaman pada lampiran yang menunjukkan kutipan tersebut berada.

Data-data yang telah terkumpul selanjutnya direduksi sesuai fokus penelitian. Menurut Miles \& Huberman (1994: 10), reduksi data bermakna proses memilih, memfokuskan, menyederhanakan, mengabstraksi dan mengubah data yang ditulis dalam catatan lapangan atau transkrip. Reduksi data pada penelitian ini dilakukan dua kali, reduksi pertama mengumpulkan poin-poin penting dari data wawancara, observasi, catatan lapangan, dan analisis dokumen yang dibutuhkan dalam penelitian dan disajikan dalam bentuk kolomkolom. Data-data tersebut mencakup proses penyusunan kurikulum, sosialisasi kurikulum bentuk implementasi kurikulum, peran guru dan pembina asrama dalam pelaksanaan kurikulum, bentuk evaluasi kurikulum, ketercapaian kurikulum dan faktor-faktor yang menjadi kendala manajemen kurikulum MAPK MAN 1 Surakarta. Selanjutnya dilakukan reduksi data yang kedua untuk menemukan data yang sama sehingga dianggap obyektif untuk dimaknai guna menghasilkan kesimpulan berupa konsep dalam proses-proses manajemen kurikulum MAPK MAN 1 Surakarta.

\section{Hasil Penelitian dan Pembahasan}

Hasil penelitian mengenai manajemen kurikulum MAPK terdiri dari empat pokok bahasan utama yaitu:

\section{Perencanaan Kurikulum MAPK MAN 1 Surakarta}

\section{Proses Penyusunan Kurikulum MAPK MAN 1 Surakarta}

Perencaanan kurikulum dilakukan melalui workshop berpedoman pada kurikulum nasional, pengembangan keunggulan lokal, dan adaptasi sistem pondok pesantren sehingga tampak kekhasan kurikulum MAPK berupa penguasaaan ilmu agama islam, bahasa arab \& inggris, dan kajian kitab yang diwujudkan dalam struktur dan muatan kurikulum mayoritas pelajaran agama Islam yang diajarkan menggunakan bahasa pengantar bahasa arab. Workshop melibatkan berbagai pihak mulai dari kepala madrasah, waka, guru, pembina asrama, dan komite madrasah agar semua aspirasi dapat terwadahi demi perencanaan kurikulum yang komprehensif dan strategis dalam menghadapi tuntutan perubahan zaman.

Kurikulum nasional yang dimaksud adalah kurikulum yang ditetapkan oleh pemerintah untuk program keagamaan terdiri dari mata pelajaran akhlak, sejarah kebudayaan islam, bahasa arab, tafsir, hadits, fiqih, dan ilmu kalam, disertai pelajaran-pelajaran yang ditetapkan dalam stuktur dan muatan kurikulum pendidikan menengah yaitu pelajaran matematika, bahasa indonesia, bahasa inggris, kewarganegaraan, pendidikan jasmani olahraga dan kesehatan, serta teknologi informasi dan komunikasi dengan total jumlah tatap muka sebanyak 45 jam per minggu. 
Kurikulum lokal adalah kurikulum yang menekankan pengembangan kemampuan bahasa arab dan inggris siswa serta keterampilan membaca dan mengkaji kitab. Mata pelajaran bahasa arab terdiri dari nasyi'in, ta'bir tahriri, ta'bir syafawi, istima' muthola'ah/qiro'ah, qowaid, balaghoh, dan tarjamah. Selanjutnya mata pelajaran untuk pengembangan bahasa inggris terdiri dari structure, listening, conversation, writing dengan alokasi waktu 18 jam per minggu. Keterampilan membaca dan memahami kitab terdiri dari beberapa kitab yang dipelajari oleh siswa siswi MAPK diantaranya hadits arba'in, kifayatul ahyar, figh sunnah, tafsir ayatul ahkam, tafsir jalalin, tafsir shofwatuttafsir, tafsir al maroghi, dan kajian keislaman berupa bahtsul masail.

Selanjutnya, kegiatan ekstrakurikuler siswa terdiri dari kegiatan-kegiatan yang mewadahi minat dan bakat siswa diantaranya firqoh kaligrafi al-hasyimie, hadrah, tilwatil qur' an dan karya ilmiah remaja. Al hasyimie yaitu organisasi yang bergerak di bidang seni kaligrafi untuk menyalurkan bakat-bakat melukis siswa, kemudian hadrah adalah kelompok musik islam yang mewadahi siswa siswi yang berbakat dalam bidang musik. Tilawatil qur'an adalah salah satu kegiatan pengembangan seni membaca al-qur'an bagi siswa siswi, selanjutnya karya ilmiah remaja adalah kegiatan yang mewadahi minat dan bakat siswa terkait penelitian karya ilmiah.

Kurikulum MAPK yang padat ini perlu direncanakan agar pelaksanaan kurikulum MAPK memiliki arah yang jelas dan menjadi pedoman bagi kepala sekolah, waka, koordinator program/pembina, guru, dan siswa, termasuk komite madrasah sebagai stakeholder dalam melaksanakan pembelajaran yang sesuai dengan tujuan pendidikan yang ditetapkan oleh madrasah yaitu mewujudkan lulusan yang mampu menguasai keilmuan islam yang berakhlaqul karimah dengan keunggulan kemampuaan bahasa arab dan inggris yang memadai untuk bersaing secara global. Perencanaan kurikulum MAPK MAN 1
Surakarta bermanfaat untuk mensinkronkan dengan visi misi madrasah, karena perencanaan diturunkan dari visi misi madrasah sehingga dapat dikatakan bahwa perencanaan kurikulum sesuai dengan fungsi perencanaan kurikulum menurut Hamalik (2008: 152) yaitu sebagai roda penggerak organisasi dan tata laksana untuk menciptakan perubahan dalam masyarakat sesuai dengan tujuan lembaga. Sejauh ini perencanaan kurikulum MAPK telah diupayakan untuk merealisasikan visi misi lembaga.

\section{Sosialisasi kurikulum MAPK MAN 1} Surakarta

Sosialisasi kurikulum dilakukan lewat berbagai media, baik lisan melalui rapat madrasah, secara tertulis melalui dokumen KTSP, brosur, surat edaran, dan secara online lewat website madrasah. Sosialisasi kebijakan yang telah dibuat merupakan langkah penting begitu juga sosialisasi kurikulum MAPK. Sosialisasi kurikulum yang utama adalah melalui rapat madrasah dimana kepala madrasah menyampaikan kurikulum kepada guru dan karyawan agar mereka paham isinya sebelum melaksanakan kurikulum. Pemahaman ini penting bagi guru karena mereka adalah ujung tombak pelaksanaan pembelajaran MAPK. Sosialisasi juga dilakukan melalui media tertulis dalam bentuk dokumen KTSP yang disusun oleh tim penyusun kurikulum MAN 1 Surakarta, dokumen ini dapat dipelajari oleh seluruh guru MAPK yang dikelola oleh waka kurikulum. Bentuk lain sosialisasi kurikulum adalah melalui surat edaran madrasah tentang pembagian jam mengajar guru, jadwal pelajaran itu merupakan bagian dari sosialisasi kurikulum. Saat kepala madrasah memberikan pengarahan kepada guru, hal tersebut juga bentuk sosialisasi kurikulum yang memberikan kesempata keapda guru untuk mengetahui lebih dalam tentang kurikulum yang diterapkan madrasah.

Sosialisasi kurikulum yang telah disebutkan di atas adalah sosialisasi kurikulum kepada pihak internal, sedangkan 
sosialisasi kurikulum kepada pihak eksternal adalah melalui website madrasah dan brosur pendaftaran siswa baru MAPK. Website madrasah di dalamnya mencantumkan desain kurikulum MAPK yang bercirikan pengajaran ilmu-ilmu agama islam, pola penyelenggaraan pendidikan, dan tenaga pengajar. Media website memudahkan masyarakat untuk mengkses informasi yang dibutuhkan tentang MAPK dari berbagai penjuru daerah mengingat peminat progam keagamaan MAN 1 Surakarta datang dari berbagai daerah. Selain itu, sosialisasi kurikulum kepada pihak eksternal juga dilakukan lewat brosur pendaftaran siswa baru untuk menyediakan informasi kepada masyarakat yang berminat mendaftarkan puta putrinya mengikuti pendidikan program keagamaan. Jadi, MAPK telah melaksanakan sosialisasi kurikulum kepada pihak internal maupun eksternal demi membuktikan bahwa program keagamaan MAN 1 Surakarta masih eksis hingga sekarang.

\section{Pelaksanaan Kurikulum MAPK MAN 1 Surakarta}

\section{Bentuk Implementasi Kurikulum MAPK MAN 1 Surakarta}

Pelaksanaan kurikulum MAPK diwujudkan melalui berbagai bentuk kegiatan termasuk pembelajaran, kegiatan asrama, dan kegiatan pengembangan diri. Pembelajaran program keagamaan terbagi menjadi tiga kelompok yaitu pembelajaran pagi, tutorial sore, dan kegiatan asrama. Beragamnya proses pelaksanaan yang terjadi di MAPK telah menjadi ciri khas MAPK dari dulu sehingga masih dipertahankan hingga saat ini demi membekali siswa siswinya dengan ilmu-ilmu islam yang memadai.

Hal yang membedakan pelaksanaan pembelajaran di MAPK dengan madrasah lain adalah penggunaan modul berupa kitab-kitab berbahasa arab untuk kajiankajian keislaman dan bahasa pengantar pembelajaran menggunakan bahasa arab sehingga fokus pembelajaran terbagi menjadi dua hal yaitu pembelajaran bahasa dan penyampaian materi pelajaran. Oleh karena itu, para guru MAPK dituntut memiliki kemampuan keilmuan dan kemampuan bahasa arab yang memadai demi mampu mengajarkan materi dengan tepat meski tidak berlatar belakang kependidikan. Pembelajaran bahasa arab sangat dipentingkan dalam pembelajaran di MAPK terbukti bahwa di dalam dokumen kurikulum MAPK tertera bahwa pelajaran nasyi' in termasuk dalam pelajaran tutorial sore hari, namun pada pelaksanaannya nasyi' in diajarkan pada pelajaran pagi. Hal ini diperkuat dengan hasil observasi yang menemukan bahwa pelajaran nasyi' in diajarkan pada jam pelajaran pagi, meski nasyi' in memang bagian dari pengembangan pelajaran bahasa arab namun pelaksanaannya tidak sesuai yang tertera dalam dokumen kurikulum. Pembelajaran tutorial dilaksanakan secara terstuktur seperti pembelajaran pagi hari dan hasil belajar siswa dinilai juga sehingga sifatnya wajib diikuti oleh seluruh siswa siswi MAPK.

Demi melengkapi pelaksanaan pembelajaran di atas, siswa siswi MAPK masih memperoleh pembelajaran setelah jam sekolah usai, yaitu pembelajaran di asrama di bawah bimbingan pembina asrama berupa kajian kitab kuning yang dilaksanakan setelah sholat maghrib dan pembelajaran mandiri mulai pukul 20.00 hingga 22.00 wib. Selain itu, masih banyak kegiatan keasramaan yang harus diikuti oleh siswa siswi MAPK diantaranya: muhadloroh, hafalan mufrodat dan kosakata inggris, muhadatsah atau conversation, tasyji'ul lughoh, arabic dan english club dan kegiatankegiatan lainnya.

Muhadloroh adalah kegiatan berpidato menggunakan bahasa arab dan inggris yang dilakukan satu minggu sekali di asrama untuk melatih kemampuan berbahasa siswa siswi MAPK yang dituangkan dalam bentuk teks pidato sesuai tema yang ditentukan oleh departemen pendidikan dan pengajaran OPPK. Melalui muhadloroh, siswa siswi MAPK dilatih untuk percaya diri mengutarakan ide-idenya di 
depan teman-teman, muhadloroh juga berfungsi sebagai ajang latihan bagi para siswa siswi MAPK sebelum mengikuti perlombaan pidato bahasa di luar madrasah.

Hafalan mufrodat wajib dilaksanakan oleh seluruh siswa ssiwi MAPK mulai dari kelas satu untuk memperkaya kosakata bahasa arab dan inggris siswa, kemudian hafalan dikoordinir oleh departemen bahasa OPPK di mana kelas XII menjadi pembimbing bagi kelas $\mathrm{X}$ dan XII untuk menyetorkan hafalan setiap hari sebanyak lima kata arab dan lima kosataka inggris dibuktikan dengan buku taftisy yang akan diperiksa oleh departemen bahasa. Muhadatsah atau conversation adalah kegiatan kebahasaan yang mendorong siswa untuk mempraktekkan kemampuan bahasa mereka dengan bercakap-cakap dengan sesama teman menggunakan bahasa arab atau inggris yang diselenggarakan pada pagi hari oleh departemen bahasa sebanyak 2-3 kali dalam seminggu. Tasyji'ul lughoh adalah pemberian kosataka atau ungkapanungkapan dalam bahasa arab dan inggris oleh departemen bahasa dan pembina asrama untuk menambah perbendaharaan kosakata siswa siswi MAPK.

Banyaknya kegiatan kebahasaan yang diselenggarakan adalah untuk memperdalam kemampuan bahasa siswa siswi karena percakapan sehari-hari di asrama dilakukan dengan berbahasa arab dan inggris. Oleh karena itu dibentuklah arabic dan english club untuk memfasilitasi siswa siswi yang memiliki minat dalam mengembangkan kemampuan berbahasanya secara mendalam di bawah bimbingan guru yang ditunjuk sebagai pembina klub bahasa.

Kemudian, pelaksanaan kurikulum MAPK juga mewadahi kreativitas siswa siswi melalui kegiatan ekstrakurikuler dalam berbagai bidang, diantaranya kelompok kaligrafi al hasyimie yang bergerak di bidang seni lukis dan dekorasi, KIR untuk memfasilitasi potensi siswa dalam bidang penulisan karya ilmiah, seni hadrah dan tilawah memfasilitasi bakat siswa siswi MAPK dalam bidang musik islam dan seni baca al-qur'an, madding dan bulletin bilingual yang memfasilitasi minat dalam bidag jurnalistik.

Semua bentuk kegiatan yang telah diuraikan adalah realisasi dari kurikulum MAPK yang memperhatikan penguasaan ilmu agama, kemampuan bahasa asing serta kreativitas siswa agar mampu mengantarkan siswanya menjadi insan yang memiliki daya saing dan mengukir prestasi di bidang akademik maupun nonakademik.

\section{Peran Kepala Madrasah, Guru dan Pembina Asrama dalam Pelaksanaan Kurikulum MAPK MAN 1 Surakarta}

Kepala madrasah sebagai pemimpin lembaga beperan memantau semua kegiatan pelaksanaan kurikulum yang terselenggara di sekolah maupun di asrama baik secara langsung maupun dibantu oleh wakamad program keagamaan. Pemantauan yang dilakukan kepala madrasah adalah keliling ke kelas-kelas untuk melihat bagaimana guru melaksanakan pembelajaran atau sekedar mengobrol dengan guru untuk mendengarkan keluhan atau kendala yang dialami oleh guru. Kemudian, kepala madrasah datang ke asrama untuk memberikan motivasi, dan dukungan kepada pembina asrama serta siswa dalam menjalankan setiap kegiatan. Beliau juga terlibat dalam kegiatan-kegiatan yang diselenggarakan oleh organisasi siswa sehingga mengetahui secara langsung bagaimana kegiatan-kegiatan terlaksana.

Peran penting kepala madrasah selaku atasan adalah menilai kinerja guru dan pembina asrama, apakah sudah sesuai dengan deskripsi kerjanya atau belum, jika belum maka perlu dicari apa penyebabnya untuk diselesaikan. Kinerja guru yang belum optimal maka perlu dilakukan pembinaan, pengarahan agar kinerjanya meningkat semisal diikutkan pelatihan, dianjurkan untuk studi lanjut demi pengembangan kemampuan dan lain sebagainya. Kepala madrasah juga memberikan kesempatan kepada setiap guru dan pembina asrama untuk mengemukakan ide atau aspirasinya terkait 
pelaksanaan kurikulum demi peningkatan kualitas pembelajaran. Ide, saran atau masukan dari guru dan pembina asrama dijadikan bahan pertimbangan dalam pengambilan keputusan kepala madrasah.

Guru sebagai ujung tombak pelaksanaan kurikulum di kelas, berinteraksi langsung dengan siswa bertanggungjawab menyelenggarakan pembelajaran yang aktif, kreatif, interaktif dan menyenangkan demi pengembangan potensi siswa. Guru mempersiapkan materi, bahan ajar, metode, alat peraga untuk menyampaikan pengetahuan baru kepada siswa. Perlu diperhartikan bahwa pembelajaran MAPK yang menggunakan bahasa pengantar bahasa arab menjadikan peran guru MAPK adalah ganda, yaitu menyampaikan materi dan mengajarkan kemampuan berbahasa kepada siswa. Guru adalah orang yang paling mengetahui bagaimana kondisi siswa saat mengikuti pembelajaran, sehingga memiliki informasi tentang apa yang dibutuhkan oleh peserta didik, kendala-kendala apa saja yang dihadapi oleh siswa dan harus segera diatasi dalam rangka mensukseskan penyelenggaraan pembelajaran.

Pembelajaran yang dilaksanakan di MAPK memiliki tujuan transfer of value bukan sekedar transfer of knowledge, jadi keberadaan guru dalam pembelajaran harus ada tidak dapat digantikan dengan alat pembelajaran atau model pembelajaran mandiri tanpa bimbingan dari guru. Ilmu-ilmu mengenai agama islam harus diajarkan dengan benar agar memberikan pemahaman tentang ajaran-ajaran agama secara benar pula, tidak salah menafsirkan karena pemahaman terhadap ilmu agam menjadi prinsip hidup siswa nantinya ketika kembali ke masyarakat.

Pembina asrama sebagai pengelola kegiatan asrama agar mendukung pembelajaran di sekolah adalah memastikan bahwa kegiatan asrama berlangsung secara berkesinambungan. Selain itu, pembina asrama memiliki peran membimbing, membina, dan mendampingi siswa dalam melaksanakan kegiatan di dalam dan luar madrasah, membantu kesulitan belajar siswa, dan menegur siswa yang melakukan pelanggaran. Seperti yang pernah diamati, pembina meluangkan waktu untuk memberikan bimbingan belajar kepada siswa siswi MAPK, atau sekedar keliling ke setiap kamar siswi untuk memastikan mereka belajar saat jam wajib belajar, memimpin apel pagi sebelum berangkat ke sekolah, membimbing tahfidzul qur'an, memberikan nasehat kepada siswa. Pembina adalah figur orang tua bagi siswa MAPK karena mereka mendampingi siswa selama dua puluh empat jam dengan tinggal bersama siswa di asrama, sehingga mengetahui betul keseharian ssiwa di asrama.

Aktivitas yang selalu mengiringi pelaksanaan pembelajaran adalah pembimbingan, ketika siswa memiliki kesulitan dapat segera dibantu, pembimbingan semacam ini dilakukan oleh guru dan pembina asrama yang mengetahui betul sejauh mana kemampuan siswa dan kendala yang dihadapi selama mengikuti pembelajaran di sekolah maupun hambatan selama mengikuti kegiatan asrama. Tugas guru dan pembina asrama selain membimbing kegiatan akademik, mereka juga berperan dalam membina kegiatan pengembangan diri siswa MAPK melalui kegiatan ekstrakurikuler. Salah satu guru MAPK diberikan tugas sebagai wakamad bidang kesiswaan program keagamaan yang mendampingi dan mengarahkan siswa MAPK dalam menjalankan kegiatan organisasi dan kegiatan-kegiatan ekstrakurikuler diantaranya firqoh kaligrafi al-hasyimie, kelompok hadrah, seni tilawatil qur'an, kegiatan jurnalistik, gebyar seni MAPK (Gesma), dan MAPK fair.

Peran kepala madrasah, guru, dan pembina asrama telah diupayakan semaksimal mungkin, meski masih mengalami kendala diantaranya berupa program pendidikan yang ada di MAN 1 Surakarta tidak hanya program keagamaan sehingga fokus kepala madrasah tidak hanya satu, terpecah kepada beberapa program yang menyebabkan minimnya waktu untuk memperhatikan perkembangan program secara detail. Kemudian kendala jumlah 
pembina yang belum seimbang dengan jumlah siswa dirasakan dampaknya oleh siswa dalam hal sulitnya memperoleh bimbingan dan pengarahan yang intensif.

Evaluasi Kuriksulum MAPK MAN 1 Surakarta

\section{Bentuk Evaluasi Kurikulum MAPK MAN 1Surakarta}

Evalusi kurikulum yang diselenggarakan MAPK adalah evaluasi hasil belajar siswa dikaitkan dengan pencapaian standar kompetensi dasar penguasaan ilmu keislaman dan bahasa asing setelah mengikuti proses pembelajaran. Evaluasi dilakukan untuk pelajaran pagi yang notabene adalah kurikulum nasional dan tutorial yang merupakan kurikulum lokal MAPK untuk menilai kemampuan siswa dari segi kognitif, afektif, dan psikomotorik. Keduanya dievaluasi dalam bentuk ujian semester dan ujian tutorial yang penyelenggaraanya menggunakan bahasa arab, soal dan jawaban menggunakan bahasa arab agar cocok untuk menilai kualitas proses pembelajaran yang juga menggunakan bahasa arab.

Bentuk evaluasi semacam ini memang berbeda dari evaluasi yang dilaksanakan untuk program madrasah pada umumnya, meskipun bernaung di satu lembaga yaitu MAN 1 Surakarta. Perbedaan lain adalah evaluasi yang diterapkan untuk tutorial hanya dilakukan oleh MAPK karena hasil belajar saat tutorial juga menentukan kelulusan siswa. Adapun evaluasi tahap akhir yaitu ujian nasional untuk program keagamaan terdiri dari mata pelajaran matematika, bahasa indonesia, bahasa inggris, tafsir dan ilmu tafsir, ilmu hadits, dan fiqih. Temuan berbeda juga dirasakan pada proses evaluasi kurikulum MAPK dimana siswa harus menghafalkan al-qur' an minimal tiga juz selama tiga tahun menempuh pendidikan di MAPK sebagai syarat pengambilan ijazah.

Hasil evaluasi kurikulum MAPK dijadikan feedback/umpan balik bagi perencaaan kurikulum MAPK selanjutnya.
Kompetensi siswa mana yang sudah tercapai, dan kompetensi mana yang belum tercapai, aspek pembelajaran mana yang perlu ditingkatkan atau aspek mana yang perlu direncanakan ulang.

\section{Ketercapaian Kurikulum MAPK MAN 1 Surakarta}

Ketercapaian kurikulum MAPK dilihat dari beberapa aspek yaitu tingkat kelulusan siswa, daya saing di luar madrasah, penguasaan kemampuan berbahasa dan penguasaan ilmu-ilmu agama islam. Selama ini tingkat kelulusan siswa MAPK mencapai seratus persen dengan nilai yang lebih tinggi dibandingkan nilai yang dicapai lulusan MAN biasa. Kemudian penguasaan ilmu-ilmu agama islam siswa MAPK cukup mendalam, mampu memahami dari sumber kitab asli berbahasa arab, penguasaan bahasa asing terlihat siswa mampu berkomunikasi dengan bahasa arab dan inggris dalam kegiatan sehari-hari, mengukir prestasi di berbagai perlombaan tingkat daerah maupun nasional.

Prestasi-prestasi siswa MAPK antara lain: juara 3 tilawah putra se-Jateng di IAIN Semarang, juara 3 kaligrafi se-Jateng di IAIN Semarang, juara 1 kaligrafi Assalam, juara 1 hadits wustho putri MQK Jateng 2011, juara 1 tilawah putra PORSENI tingkat kota Surakarta 2011, juara debat MQK Jateng 2011, juara 2 pidato bahasa inggris di UNY, juara 2 pidato bahasa arab festival kebudayaan arab UGM se-Jateng DIY 2012, juara 1 pidato bahasa indonesia di Depag 2012, juara 1 tilawah ISC 2012 di UNS, juara 1 dakwah remaja masjid agung Surakarta 2012, juara umum ISC 2012 di UMS, juara 2 al-barjanji di masjid agung Surakarta 2013 dan penyanyi solo terbaik 2013, juara 2 kaligrafi mushaf POSPEDA Surakarta 2012, Juara 1 kaligrafi lukis POSPEDA Surakarta 2011, juara 1 musikalisasi puisi arab di UMS 2012. Keberhasilan siswa MAPK mengukir prestasi di berbagai bidang tersebut menunjukkan kualitas kurikulum MAPK yang mampu membekali siswa dengan berbagai 
keahlian, baik di bidang akademik maupun nonakademik.

Secara umum dapat dikatakan bahwa pencapaian kurikulum MAPK MAN 1 Surakarta telah berhasil karena semua aspek yang disebutkan di atas telah terpenuhi sehingga mampu mengantarkan siswanya untuk melanjutkan pendidikan ke jenjang perguruan tinggi baik perguruan tinggi di dalam maupun di luar negeri. Secara konsisten MAPK berhasil mengirimkan lulusannya ke universitas di timur tengah setiap tahun, sedangkan lulusan yang melanjutkan pendidikan di universitas dalam negeri tersebar di berbagai perguruan tinggi.

Kendala dalam Manajemen Kurikulum MAPK MAN 1 Surakarta

Kendala yang dihadapi oleh MAPK dalam melaksanakan manajemen kurikulum muncul dari berbagai faktor diantaranya modul untuk program keagamaan belum baku dan kitab muqorror kurang sistematis, sarana prasarana yang belum memadai, masalah kedisiplinan anak, padatnya kegiatan mengurangi fokus belajar anak, dan kemampuan bahasa anak yang belum mampu memahami teks secara keseluruhan.

Modul untuk materi program keagamaan belum memilik standar baku, selama ini buku-buku yang digunakan adalah buku-buku atau kitab-kitab yang digunakan pada tahun sebelumnya. Ketika ada perubahan pun disesuaikan dengan kebutuhan pembelajaran atau atas inisiatif guru mata pelajaran yang mengusulkan modul untuk materi program keagamaan. Kemudian kendala lain terkait modul adalah belum sistematisnya buku ajar (muqorror) pada pembelajaran pagi dengan tutorial sore hari, padahal tutorial digunakan untuk memperdalam materi pembelajaran pagi. Artinya materi pada pembelajaran pagi tidak dibahas lagi pada saat tutorial karena perbedaan urutan materi atau perbedaan sumber kitab asli yang digunakan, hanya cocok di awal kemudian selanjutnya sudah berbeda bahkan pokok bahasan tidak saling berkaitan. Hal ini menyebabkan pemahaman siswa terhadap materi menjadi terkotak-kotak oleh perbedaan materi.

Kendala faktor sarana adalah padatnya kondisi asrama sehingga suasana pembelajaran kurang kondusif untuk kegiatan, peningkatan sarana prasarana pun harus dilakukan secara bertahap sesuai urutan prioritas madrasah meski terkadang kebutuhan sarana prasarana MAPK sudah mendesak. Kondisi laboratorium bahasa sedang mengalami kerusakan yaitu tidak adanya peralatan audio untuk pelaksanaan pelajaran bahasa terutama listening sehingga pembelajaran bahasa menjadi terhambat. Pada akhirnya guru hanya menggunakan peralatan audio berupa speaker yang kurang representative untuk pelajaran bahasa terkait pengembangan listening skill.

Kegiatan MAPK memang sangat padat dari pagi hingga malam hari sehingga berdampak pada kedisiplinan siswa dalam mengikuti proses pembelajaran, kadang siswa terlambat atau merasa capek sehingga tidak fokus saat mengikuti kegiatan. Selain itu, siswa juga disibukkan dengan kegiatan organisasi sehingga pikiran tidak fokus pada pembelajaran justru cenderung fokus pada kegiatan-keagiatan organisasi. Kondisi seperti ini dikeluhkan oleh guru sebagai salah satu hambatan proses pembelajaran di kelas. Selanjutnya kendala yang dihadapi selama pelaksanaan pembelajaran berlangsung adalah masalah bahasa siswa. Dalam artian kemampuan bahasa siswa masih kurang dalam memahami teks berbahasa arab sehingga pemahaman terhadap materi pun menjadi terhambat, meski banyak kegiatan kebahasaaan telah diselenggarakan ternyata belum menghasilkan kemampuan bahasa anak yang optimal, terutama kelas $X$ yang masih harus diartikan satu per satu tiap kata oleh guru dalam proses pembelajarannya.

Kendala dari faktor guru adalah kesadaran dan ketelatenan guru MAPK dalam membuat perangkat pembelajaran masih kurang, padahal perangkat pembel- 
ajaran adalah pedoman dalam melaksanakan pembelajaran yang sistematis demi ketuntasan belajar siswa. Meski begitu, guru tetap mengajar dan secara perlahan melengkapi pembuatan perangkat pembelajaran setelah mendapatkan pelatihan dari pihak madrasah. Selanjutnya, kemampuan guru dalam penguasaan teknologi komputer masih kurang sehingga belum dapat menciptakan bahan ajar yang menarik bagi siswa agar pembelajaran tidak membosankan. Sejauh ini guru sebatas menggunakan power point, video, atau gambar-gambar demi mendukung penyampaian materi kepada siswa.

\section{Simpulan dan Saran}

1. Perencanaan kurikulum MAPK dilakukan melalui workshop dengan berpedoman pada kurikulum nasional, pengembangan keunggulan lokal, dan adaptasi sistem pondok pesantren sehingga tampak kekhasan kurikulum MAPK berupa penguasaaan ilmu agama islam, pengembangan kemampuan bahasa arab dan inggris, serta kajian kitab yang diwujudkan dalam struktur dan muatan kurikulum mayoritas pelajaran agama islam berupa ilmu tafsir, hadits, fiqih, akidah akhlak, sejarah kebudayaan islam, yang diajarkan menggunakan bahasa pengantar bahasa arab. Kurikulum yang telah disusun kemudian disahkan dan disosialisasikan kepada pihak internal dan eksternal madrasah.

2. Pelaksanaan kurikulum MAPK terealisasi dalam berbagai bentuk kegiatan berupa pembelajaran pagi, tutorial sore hari, tahfidzul qur'an, kegiatan asrama, pengembangan bahasa arab dan inggris (muhadloroh, language fair, tasyji'ul lughoh, muhadatsah), serta kegiatan ekstrakurikuler (kaligrafi, hadrah, KIR) demi mengembangkan potensi siswa dalam penguasaan ilmuilmu islam, kemampuan bahasa asing, dan kreativitas siswa. Pihak yang bertanggungjawab dalam pelaksanaan kurikulum adalah kepala madrasah sebagai pengambil keputusan, guru sebagai administrator pembelajaran, dan pembina asrama sebagai koordinator kegiatan asrama saling mendukung demi suksesnya pelaksanaan kurikulum MAPK.

3. Evaluasi kurikulum dilakukan untuk menilai hasil belajar siswa yang dilaksanakan dalam bentuk ujian semester, ujian madrasah dan ujian nasional dengan bahasa arab untuk muatan kurikulum nasional dan muatan kurikulum lokal. Hasil evaluasi kurikulum menunjukkan bahwa kurikulum MAP$\mathrm{K}$ berhasil mencapai tujuan penyelenggaraan pendidikan program keagamaan dilihat dari tingkat kelulusan, daya saing dan penguasaan siswa terhadap ilmu agama dan bahasa asing (arab dan inggris).

4. Faktor-faktor kendala manajemen kurikulum MAPK yaitu modul program keagamaan belum baku tidak adanya pedoman dari departemen agama untuk buku-buku sumber yang digunakan dalam pembelajran program kegamaan dan kitab muqorror/buku diktat kurang sistematis; ketelatenan guru membuat perangkat pembelajaran dan penguasaan teknologi komputer masih kurang; sarana prasarana yang belum memadai/minim; masalah kedisiplinan siswa-siswi MAPK dalam mengikuti pembelajaran; padatnya kegiatan sekolah, asrama, dan organisasi mengurangi fokus belajar anak; dan kemampuan bahasa anak yang belum mampu memahami teks secara keseluruhan.

Saran

Berdasarkan simpulan di atas, maka saran yang dikemukakan adalah:

1. Memperkuat kemampuan berbahasa siswa dengan memberikan kosakatakosakata baru terkait pelajaran sehingga membekali siswa dengan perbendaharaan kata yang relevan dengan materi pelajaran. 
2. Menentukan standar buku modul yang akan dipakai program keagamaan berkoordinasi dengan para guru MAPK dan berkonsultasi dengan pakar atau ahli di bidang pengajaran ilmu-ilmu agama Islam.

3. Membuat skala prioritas dalam perencanaan sarana prasarana MAPK agar sarana yang mengalami kerusakan segera diperbaiki oleh madrasah.

4. Memberikan pelatihan kepada guru tentang administrasi pembelajaran dan teknologi komputer dalam rangka membuat media pembelajaran yang menarik.

\section{Daftar Pustaka}

Bueraheng, I. (2010). Manajemen kurikulum program pendidikan agama islam kelas tsanawiyah di madrasah azizstan Thailand. Tesis, tidak dipublikasikan, Universitas Negeri Yogyakarta.

Engkoswara \& Komariah, A. (2010). Administrasi pendidikan. Bandung: Alfabeta.

Glatthorn, A. A., Boschee, F. \& Whitehead, B. M. (2009). Curriculum leadership: strategis for development and implementation (2nd ed). United States of America: Sage Publication.

Hamalik, O. (2008). Manajemen pengembangan kurikulum. Bandung: PT.Remaja Rosdakarya

Lunenberg, F. C. \& Orstein, C. A. (2000). Educational administration: concept and practices $\left(3^{\text {rd }} \mathrm{ed}\right)$. United States of America: Wadsworth

Miles, M. B. \& Huberman, A. M. (1994). Qualitative data analysis ( $\left.2^{\text {nd }} e d\right)$ : an expanded sourcebook. United States of America: Sage Publication.

Mudlofir, A. (2011). Aplikasi pengembangan kurikulum tingkat satuan pendidikan dan bahan ajar dalam pendidikan islam. Jakarta: PT. Raja Grafindo Persada.

Nugroho, S. (2008). Manajemen kurikulum kelas internasional di SMA negeri 1 kota Yogyakarta. Tesis, tidak dipublikasikan, Universitas Negeri Yogyakarta.

Parkay. F. W., Hass, G. J. \& Anctil, E. J. (2010). Curriculum leadership: readings for developing quality educational programs (9th ed). Boston: Pearson Education Inc.

Qomar, M. (2002). Manajemen pendidikan islam. Malang: Erlangga.

Rivai, V \& Murni, S. (2010). Education management: analisis teori dan praktik. Jakarta: PT. RajaGrafindo Persada.

Sanjaya, W. (2008). Kurikulum dan pembelajaran: teori dan praktik pengembangan kurikulum tingkat satuan pendidikan (KTSP). Jakarta: Prenada Media Group.

Sukmadinata, N. S. (2012). Pengembangan kurikulum: teori dan praktek. Bandung: PT.Remaja Rosdakarya. 